\title{
Money Growing on Trees: A Classroom Game about Payments for Ecosystem Services and Tropical Deforestation
}

August 9, 2019

\author{
Sahan T. M. Dissanayake and Sarah A. Jacobson*
}

\begin{abstract}
(125 words):
Payments for ecosystem service programs use a market-based approach to pursue environmental goals. While they are common policy tools, key concepts that can determine their efficacy are nuanced and hard to grasp. We present a new interactive game that explores the functioning and implications of payments for ecosystem service programs. Participants play the role of rural households in a developing country. They decide individually or as groups whether to enter into contracts to receive payment from the United Nations REDD+ program to refrain from harvesting from a local forest. The game explores topics including: payments for ecosystem services programs; climate change; tropical deforestation; cost-effectiveness; additionality; contract fraud and enforcement; and community resource management. We provide customizable materials, a detailed reading list, and prompts for discussion.
\end{abstract}

Keywords: classroom game, payments for ecosystem services, REDD+, market-based regulation

JEL Codes: A22, Q23, Q54, Q56, Q57, Q58

\footnotetext{
*Sahan T. M. Dissanayake (sdissan2@gmail.com, Twitter@sahanorg, ORCID 0000-0002-4342-5979) is at Portland State University. Sarah A. Jacobson (saj2@,williams.edu, Twitter@SarahJacobsonEc, ORCID 0000-00022052-5627) is at Williams College. Jacobson is the corresponding author.

Feedback on the game is very welcome; please let us know how it works for you!
} 


\section{Introduction}

Payments for ecosystem service programs are market-based (that is, incentive-based) tools for environmental regulation and have been used to address important environmental issues like watershed management, deforestation, species preservation, and non-point source pollution (Engel, 2016; Engel et al., 2008; Wunder, 2005). However, key concepts about them can be hard to convey and grasp. We describe a new interactive game, set in the context of tropical deforestation, that explores issues with payments for ecosystem service programs. This detailed, context-rich game is well suited to many classes, particularly those on environmental and resource economics and environmental policy, and to trainings for policymakers and researchers.

Deforestation is extensive worldwide, with over $50 \%$ of forests having been converted to human use since the advent of agriculture. This is especially a concern in developing countries, with tropical forest area decreasing at over 10 million hectares per year (Bluffstone, 2013; Millennium Ecosystem Assessment, 2005; Pan et al., 2011). This is consequential because forests provide global public goods, including providing a sink for greenhouse gas emissions. The United Nation's Framework Convention on Climate Change (UNFCCC) established the REDD+ program to fight deforestation and forest degradation using payments for ecosystem services. While large-scale conversion for agriculture is a cause of deforestation in some cases, in other cases deforestation and forest degradation happen as communities living in or near forests harvest firewood and other material, especially as a result of economic pressures. We depict this more diffuse form of deforestation in this game.

In our game, participants play the role of rural households in a developing country. The game progresses through scenarios in which the households individually or as communities 
decide whether to enter into REDD + contracts that will pay them to refrain from harvesting from a local forest. We have designed a set of treatments that can be mixed and matched to provide hands-on learning experiences with topics including: payments for ecosystem services programs; climate change; tropical deforestation; cost-effectiveness and opportunity cost; additionality; contract fraud, auditing and enforcement; community decision-making and common pool resource management; and the challenges facing rural households in developing countries.

The game is suitable for undergraduate or graduate classes covering a variety of subjects, including environmental or resource economics, public economics, environmental policy, and development economics, and for continuing education or capacity-building training for policymakers and researchers. It is best suited for groups of 10 to 60 players, though it can be used in larger groups, and can take 45 to 90 minutes, depending on which treatments and extensions you use. We also provide a wealth of materials to make it easy for you to customize and run the game, including an Excel recording spreadsheet that automates all relevant calculations, Instructions and Recording Sheets for participants (Appendix I), a Handout you can provide to participants with background information (Appendix II), an Instructor How-To to for you (Appendix III), and slides you can use if desired. In this paper, we discuss the game at a higher level and provide theoretical and conceptual background, suggested readings, discussion prompts, and ideas for different ways to modify and use the game.

This game has been played in multiple academic settings, ranging from a R1 research university to liberal arts colleges, and has also been used in the training of policymakers and for capacity-building for mid-career professional in developing countries. Participants have given strongly positive feedback about the game; for example, nearly all post-game survey respondents 
agreed that the game helped them understand payments for ecosystem services programs and that the game was a good use of time.

This paper proceeds as follows. First, we provide some background on the policy context and the economic issues highlighted by the game. Next, we give suggestions for readings to share with participants, including more and less technical and readings for different kinds of audiences. Next, we describe the game and how to play it. We then give suggestions for discussions relating to the game. We next discuss the feedback we have received from past game play. Before concluding, we detail some possible modifications and extensions you might consider to fine-tune the game to your interests.

\section{Background: Climate Policy, REDD+, and Forest Conservation in Developing Countries}

Over $50 \%$ of global forests have been converted to human use since the advent of modern agricultural practices and in that time, 29 countries have lost over $90 \%$ of their forests (Millennium Ecosystem Assessment, 2005). Tropical forest area is decreasing at over 10 million hectares per year, with much of the deforestation occurring in developing countries (Millennium Ecosystem Assessment, 2005; Pan et al., 2011). Nearly half the world's population relies on solid fuels like wood or charcoal for cooking, and the main direct use of forest ecosystems in low income countries is the harvesting of biomass for cooking and heating. The number of people in Africa using biomass for these purposes is projected to increase in the next decade from 793 million in 2014 to 823 million in 2030, after which it should start decreasing, but slowly: it is only projected to drop to 708 million by 2040 (Bluffstone, 2013; Chao, 2012; OECD, 2017). Forests provide important ecosystem services locally, regionally, and globally. In particular, deforestation has direct implications for climate change: over the past 150 years, 
deforestation has caused an estimated $30 \%$ of the atmospheric build-up of $\mathrm{CO}_{2}$ (Brown, 1998), and current deforestation and forest degradation accounts for $11-24 \%$ of the flow of annual greenhouse gas emissions (IPCC, 2014; Saatchi et al., 2011; Van der Werf et al., 2009). Curbing deforestation and forest degradation and improving forest management is likely to be a highly cost-effective way to address climate change and support climate adaptation (Angelsen, 2009; McKenney et al., 2004; Stavins and Richards, 2005; Stern, 2006).

As a result, restoring forests and preventing forest degradation can be a vital part of greenhouse gas emissions reduction initiatives. The 2015 Paris climate accord committed signatories to limit "the increase in the global average temperature to well below $2^{\circ} \mathrm{C}$ above preindustrial levels." When countries laid out their plans for emissions reductions, the Paris accord was the first to count countries' efforts to plant or protect forests as part of their climate commitments (Griscom et al., 2017; Popkin, 2019). The resulting climate impact could be substantial: Bastin et al. (2019) find that "there is room for an extra 0.8 billion hectares of canopy cover, which would store 205 gigatonnes of carbon.”

How, then, can forests be leveraged to fight climate change? REDD ${ }^{1}$ is a payments for ecosystem services (PES) system created under the United Nation's Framework Convention on Climate Change (UNFCCC) to reduce deforestation and forest degradation. REDD+ seeks to increase investment in forest management by creating a market for ecosystem services that links providers of carbon sequestration (typically landowners and farmers in tropical countries) with

\footnotetext{
${ }^{1}$ The original program was called REDD, an acronym for Reduced Emissions from Deforestation and forest Degradation; it focused only on carbon sequestration and allowed no forest use. The program was revised to "REDD+" ("REDD plus"), which allowed sustainable forest management and encouraged conservation of forests, with a goal of enhancement of carbon sinks. The "+" in REDD+ stands for other co-benefits that have been added to the original REDD program to address potentially negative, unintended effects on non-carbon ecosystem services and mitigate the program's effects on the people who currently have claims to forests (Baker et al., 2019; Bluffstone, 2013; Bluffstone et al., 2013; Rakatama et al., 2017). A new iteration, REDD++, adds a focus on low-carbon but high-biodiversity land.
} 
beneficiaries and buyers in developed countries (Baker et al., 2019; Bluffstone, 2013; Bluffstone et al., 2013; Rakatama et al., 2017). The program effectively provides financial incentives to release less, and sequester more, emissions. It thereby could yield many benefits, including reducing carbon emissions and deforestation, achieving critical development goals, enhancing forest governance, and contributing to poverty reduction (Bluffstone et al., 2013; Economist, 2010; Sims and Alix-Garcia, 2017; Springate-Baginski and Wollenberg, 2010; Toni, 2011). As of 2014, about 64 counties were engaged in conducting about 300 pilot REDD+ projects (Sills et al., 2014; UN-REDD, 2015).

Two common challenges faced by payments for ecosystem services programs in general, additionality and leakage, are notable concerns with regard to REDD+ (Engel et al., 2008; Joseph et al., 2013; Salas et al., 2018). Additionality, the participation of individual that would not harvested the forest, results in paying someone to "prevent" a forest reduction or degradation that would not have occurred. Non-additional payments waste funds that could be used to actually achieve the program's ecosystem preservation goals, and as a result decreases the efficacy of the program (Alix-Garcia et al., 2012; Balooni and Lund, 2014; Harrison and Paoli, 2012; Salas et al., 2018). Leakage occurs in this context when the protection of forests through REDD + causes other forest areas that are not protected to be cut or degraded. The resulting spillover decreases the effectiveness of REDD+ as the net reduction in deforestation is less than expected (Alix-Garcia et al., 2012; Balooni and Lund, 2014; Harrison and Paoli, 2012). Both additionality and leakage mean that headline numbers of amount of forest preserved cannot be taken at face value: careful study must be done to determine the counterfactual amount of deforestation that would have occurred if the program had not been in place. 
Another major challenge for REDD+ and related programs is verifiability: because REDD + contracts are often adopted in remote areas, monitoring is difficult, and as a result, compliance and enforcement can be challenging (Engel, 2016; Engel et al., 2008; Honey-Rosés et al., 2009; Joseph et al., 2013; Sloan and Pelletier, 2012). Land protected by a REDD+ contract may be secretly deforested or degraded, or a given parcel may be resold for offsets multiple times. However, new statistical techniques with more detailed data from satellite monitoring of forests may help fight these issues (Alix-Garcia et al., 2012; Honey-Rosés et al., 2011; Olander et al., 2008; Sloan and Pelletier, 2012).

Community forestry management has been proposed as a means to not only to halt deforestation and forest degradation but also to craft institutional mechanisms for equitable benefit sharing in communities. About $25 \%$ of developing country forests, or three times as much as is owned by the private sector, is owned by communities (Agrawal et al., 2008; Bluffstone, 2013; Bluffstone et al., 2013; Chhatre and Agrawal, 2009). Therefore, the successful adoption of REDD+ in developing countries will depend on the effectiveness of REDD+ in community-controlled settings. Community-controlled forestry requires coordination between community members, but, as discussed by Ostrom (1990, 2010), Bluffstone et al. (2013) and Agrawal et al. (2008), such coordination can be challenging.

\section{Suggested Readings to Complement the Game}

Most simply, you can distribute the Handout we provide (Appendix II) to give a brief overview of climate change, deforestation, and REDD+. It is a single page, double-sided, and cites many references. 
Beyond that, you can ask students to read about deforestation and payments for ecosystem services programs before the session. If you are using the game in the context of a course, your textbook may have useful resources. You may want to assign academic papers on climate change (Angelsen, 2009; McKenney et al., 2004; Stavins and Richards, 2005; Stern, 2006), deforestation and climate change (Angelsen, 2008; Bastin et al., 2019; Griscom et al., 2017; Popkin, 2019), programs to prevent deforestation like REDD+ (Angelsen, 2009; Bluffstone, 2013; Bluffstone et al., 2013; Economist, 2010; Lubowski and Rose, 2013; Ostrom, 2010; Sills et al., 2014; Springate-Baginski and Wollenberg, 2010; Toni, 2011; UN-REDD, 2015), or common pool resources and community management (Agrawal et al., 2008; Chhatre and Agrawal, 2009; Ostrom, 1990, 2010). Pattanayak et al. (2010) provide a comprehensive review of studies of payments for ecosystem services programs in developing countries with skeptical conclusions about their de facto effectiveness. In her Nobel Memorial Prize acceptance speech, Ostrom (2010), provides an accessible, broad overview of community governance and common property management. Another article we have found useful is the brief and accessible Jayachandran et al. (2017), which uses a randomized controlled trial to measure the efficacy of a REDD+ program in conserving forest. For a short and illuminating discussion of how forest restoration can be a means to many ends, including climate mitigation, the Nature Perspective by R. Chazdon (2019) and the Nature News Feature by Popkin (2019) can be useful. A longer report by the World Resources Institute (Brown, 1998) provides more details on these topics.

A discussion of issues relating the success of payments for ecosystem service programs like leakage, illegal harvest, enforcement, and governance can be very productive and introduce participants to the practical issues encountered when implementing policies. We recommend Engel (2016), Ostrom (1990), Balooni and Lund (2014), Bluffstone (2013), and Harrison and 
Paoli (2012). On enforcement, you can use recent relevant studies like Honey-Rosés et al. (2009), or link back to an older and broader literature on rational crime, going back to Becker (1968). The game also provides a good opportunity to discuss methods to evaluate success of conservation programs and to discuss impact evaluation more generally. We recommend AlixGarcia et al. (2012), Baylis et al. (2016), Honey-Rosés et al. (2011), and Olander et al. (2008); Shah and Baylis (2015) for both the methods and the applications.

Recent journalistic articles or blog posts about issues of global warming, deforestation, general payments for ecosystem services programs, and REDD+ can highlight the relevance of these programs in current policy discussions; a quick internet search for news items with these keywords will let you choose a story that is fresh and relevant. Song (2019), a report by ProPublica, provides an engaging and highly accessible dive into some pitfalls involved with forest-based offsets. The website for the UN-REDD+ program, https://www.un-redd.org/ and the UN-REDD bi-monthly multi-lingual newsletter, https://www.un-redd.org/newsletter-archive, also have a wealth of additional information on a broad array of topics relating to REDD+.

\section{The Game}

Participants in the game play the role of rural households in a low-income tropical country. Each household is part of a small community located in a rural area on the margin of a forest. The community supports itself primarily through small-scale agriculture in households' garden plots (subsistence farming) and from harvesting wood and non-timber forest products such as fruits, nuts, medicinal plants, fish, game, bark, and fibers from the local forest. The game consists of a series of rounds (or "contract periods"), and in each round, participants make individual and/or group decisions about whether to harvest from or conserve the forest. Across 
the rounds, you lead participants through a series of treatments that vary the policy environment and actions available to demonstrate different concepts.

We will not duplicate here the detailed instructions and information from the materials we provide along with this paper. Instead, we will discuss some higher-level points about the game, describe the treatments and discuss theoretical points about expected behavior in them, list the materials we provide, explain how you set up and run the game, and suggest what to do when the game is complete. Our discussion here is narrative in form and provides background to help you decide whether and how to use the game, whereas the Instructor How-To (Appendix III) provides specific steps for you to follow and the Instructions and Recording Sheet (Appendix I) is for the participants.

\section{Higher Level Points about the Game}

This game is, at heart, a role-playing game. Participants put themselves in the role of people who live in a forest-dependent community in a developing country, and who engage in subsistence farming and harvest from the forest. They make a series of decisions as individuals and as groups regarding forest harvest and adoption of contracts to prevent deforestation.

The game generates variation in opportunity cost of participating in these contracts by randomly distributing numbers (we use playing cards) to represent the forest harvest values. Harvest values vary for many reasons in real life situations (such as characteristics of the forest, the household, and the locations), and these are often useful to discuss.

The game stipulates that the forest is commonly owned, but is so large that no-one's harvest affects anyone else through forest degradation; and indeed, the global public good nature of fighting deforestation is abstracted and only appears in the form of REDD+ payments that are offered from some external agent through the country's REDD+ Secretariat. As most public 
good or common pool resource issues are thus removed from the game, most of the pedagogical focus of the game is on incentive and monitoring issues, as well as community management.

Again, the core decision participants make in each round is whether to adopt a REDD+ contract, which would theoretically forbid forest harvest, although in some treatments it is possible to commit fraud by harvesting while under contract. In each round, participant decisions translate into "earnings" based on this general formula:

Earnings $=$ Farming Income + REDD + Payments + Forest Harvesting $-($ Policing/Fines $)$

The Farming Income comes from the subsistence farming on the plot of land in each participant's household and is $\$ 70$ in most treatments. The REDD+ Payment is the payment for participants who take a REDD+ contract to prevent deforestation and is $\$ 50$ in most treatments. ${ }^{2}$ The Forest Harvesting is the amount received from harvesting from the forest and is heterogenous across the participants and is determined randomly (as noted above, through cards distributed among participants). The Policing or Fines is only present when participants are allowed to engage in fraud and is the additional costs from fines or to finance policing.

We provide a spreadsheet for recording participant decisions. Based on the decisions entered, the spreadsheet automatically calculates harvest outcomes, enforcement, and fines in relevant scenarios, as well as each participant's individual welfare. To ensure that participants consider their decisions carefully, at the end of the session, we recommend picking one or more participants to earn actual money proportional to the sum of their earnings in all rounds; our spreadsheet has tools to help you do this. As discussed in Holt (1999), real incentives can improve attention and thus comprehension. We also suggest that you help students understand

\footnotetext{
${ }^{2}$ Participants should consider this a net benefit from contract adoption that comprises both the money from REDD+ and any additional value (e.g., labor earnings) from the time that has been freed up that would have otherwise spent harvesting from the forest.
} 
the human stakes involved in the real life situation that this game simulates. As one way to do this, our instructions state that if the household does not earn a minimum amount, the family is unable to eat for a day and any babies in the family will cry all night; the spreadsheet highlights participants who enter this condition, and you can call attention to that.

\section{Treatments}

We have designed six treatments for this game. The materials we provide run through each of the six treatments once, for six rounds total, but you can modify that as you please; for example, you can repeat or cut a treatment as desired. Each treatment adds one or two features to the baseline decision environment: the ability to commit contract fraud, uncertainty in earnings, auction payment instead of flat payment, and community-level decision-making.

Baseline: this is our simplest treatment: participants choose whether to harvest from the forest and get their harvest value, or take the REDD+ contract for a flat $\$ 50$ payment. Fraud is not possible. It provides a good baseline to establish understanding of the basic ways in which payments for ecosystem services programs function. Only those with lower harvest values should take up contracts; specifically, those with card values 4 and lower have an incentive to take the contracts, those with a card value of 5 are indifferent between taking and not taking a contract, and those with higher cards have an incentive to not take a contract.

Baseline + Fraud: this treatment adds the option to harvest even if a participant has adopted a REDD+ contract. There is a probabilistic audit ( $25 \%$ chance); those caught committing fraud must give up their REDD+ payment and harvest value plus pay a $\$ 70$ fine. The expected net gain from taking a contract and not committing fraud is 50 -HarvestValue, which is positive

for cards 5 and lower; the expected net gain from taking a contract and committing fraud is $0.75 * 50+0.25 *(-($ HarvestValue $)-70)=20-0.25 *$ HarvestValue, which is positive for cards 
8 and below. If a participant is risk neutral, she will take a contract and commit fraud if $50-$ HarvestValue $<20-0.25 *$ HarvestValue, which is true if $30<0.75^{*}$ HarvestValue or for cards greater than 4 . Thus, risk neutral people with purely pecuniary preferences will take a contract and not commit fraud for cards up to 4, will commit fraud for cards from 4 to 8 , and will not take a contract for cards from 8 to 10 . This treatment lets you discuss the model of rational crime and deterrence, which also underlies most modern study of regulatory enforcement; it also gives you an opportunity to discuss risk preferences and aversion to lying or cheating.

Harvest Uncertainty: in this treatment, a random force (we call it a plague of locusts, but you can change it to retain relevance if you change the setting) adds variance to the harvest value without changing the mean. Risk neutral participants will not change their behavior relative to the Baseline, but risk averse people become more likely to take the REDD+ contract. This treatment lets you talk about the insurance role these contracts can play.

Auction: here, instead of REDD+ contracts being made based on a posted price contract payment offer with voluntary take-up, participation is based on a procurement auction, as it is in many payments for ecosystem services programs. The auction mechanism is theoretically incentive compatible: the contract administrator accepts the lowest bids up to the target number of contracts, and people who get contracts are all paid the amount of the lowest bid that was not accepted. Risk neutral bidders should place a bid equal to their cost of participation, which is their opportunity cost: the harvest value that they'd have to forego. If the cards are randomly distributed with values $1-10$, then on expectation, in a symmetric equilibrium with full knowledge of perfect rationality of other players, people will bid their Harvest Value, and cards 1 through 5 will get contracts and will get paid $\$ 60$. Because the cards have discrete values, there 
may be tied bids, and if there is a tie at the median bid, for simplicity the spreadsheet will accept all of those tied bids, which might give contracts to $50 \%$ of bidders or more or less than that.

Participants might rationally shade their bids away from their true values because of their knowledge of the distribution of true values and because of guesses about how rational other participants are. Collusion among bidders to drive up the price is also theoretically possible, though we have not seen it in practice. Savvy participants might note that since the number of contracts that will be granted is essentially fixed, any participant's bid has no effect on the amount of conservation; therefore, individual tastes for conservation should not affect bidding in this treatment. This treatment gives you opportunity to talk about a variety of topics, from mathematically how one can prove incentive compatibility to the nuts and bolts of an auction implementation to procurement auction collusion to the informational benefits of auctions when policymakers don't know the distribution of opportunity costs.

Community Contract: in this treatment, you will organize the participants into groups that will function as communities to make the REDD+ contract participation decision. Each community must make two decisions: whether to adopt a contract and, if so, how the contract payments are to be divided in the group. It is important to emphasize this latter decision, as it is not a feature of prior treatments and groups may default to a "fair" equal division without thinking about it; if you want to nudge them on this point, you might point out that people with different cards have different benefits from a community contract. We suggest randomly assigning participants to groups. ${ }^{3}$ As we have designed it, there are no rules for how the group is to interact because there can be some interesting endogenously emergent decision-making

\footnotetext{
${ }^{3}$ The physical act of moving participants around the room to find their community members takes time and space as compared to the case in which you use people who are already spatially adjacent as groups. (You could see physical movement as a feature, rather than a bug, though, as getting the blood going can heighten energy mid-session.)
} 
processes. If you prefer, you can add rules to ensure specific points arise. For example, you could assign some people to be local elites who get more say in the decision than others do. This treatment lets you talk about the importance of community owned forests in many developing countries, as well as community governance and informal governance more generally. Issues of within-community inequality and power dynamics can also arise.

Community Contract + Fraud: this is the most complicated and time-consuming treatment. Because it builds on the Community Contract treatment, we recommend that you run that treatment before running this one. In this treatment, community decision-making determines contract adoption and sharing of contract payments, as in the previous treatment; however, in addition, individuals have the option to secretly commit fraud by harvesting even though the community has a REDD+ contract. In this case, the probability of an audit is not exogenous as it is in the earlier Fraud treatment: rather, it becomes more likely as more people in the community commit fraud (since forest degradation will become more obvious). Because there is a possibility of individual fraud, and because any fraud the government detects in the community will cause everyone to be penalized, the community can choose as a group to conduct costly self-policing, which will make fraud impossible. You might want to run this treatment more than once (if you have time) for both comprehension and interpersonal interaction reasons. While this treatment is complex, in our experience, participants enjoy the opportunity to test (and sometimes violate) each other's trust. This treatment gives you the opportunity to discuss self-governance and intracommunity trust issues.

\section{Materials We Provide}

All of the materials we provide are editable, so you can customize them to your needs. 
Instructions and Recording Sheet: (Appendix I): this is for the participants. It explains the game setup overall and detailed specific information about how each treatment works, and provides a place for the participant to record decisions.

Handout (Appendix II): a short, reference-dense background reading for participants. Instructor How-To: (Appendix III): a bullet-point, step-by-step summary for you on the mechanics of running the game, including preparation before, and steps during, the session.

Excel spreadsheet: this workbook has a worksheet for each treatment, a worksheet of parameters you can adjust that affect the calculations on all of the other sheets, and a summary sheet that calculates final earnings based on decisions across rounds. All columns in which you will record participant information and decisions are conveniently highlighted in yellow.

Slides: optional, to show to participants as you play the game. The slide deck provides background about climate change, deforestation, and REDD+, has a slide for each treatment summarizing key points, and ends with discussion questions.

\section{Setup and General Conduct}

We suggest you plan for the game to take a single 75-minute period or one 50-minute period plus some time during a following session for discussion. However, you could cut treatments and relegate discussion to online or other modes of exchange to make it take as little as 30 minutes in person, or you could plan detailed in-session work for before and after the game so that the whole activity takes as much as three 75 minute periods. In this section we describe the game conduct in narrative detail, but we also provide an action-oriented Instructor How-To (Appendix III) for running the game.

Send the Instructions and Recording Sheet (Appendix I) and any readings (such as the Handout we provide in Appendix II) to participants in advance and ask them to read them before 
the session. You can modify the instructions and the game to suit your needs and interests. In particular, you may pick the treatments that are most relevant to the topics of the course or training session. You may want to also modify the name of the fictional country, e.g., to be a play on a school mascot.

During the game, we use an Excel spreadsheet projected at the front of the room to record decisions and calculate earnings. Earnings calculations are complicated, especially in community rounds, so a tool like our spreadsheet is essential to make play smooth and straightforward. ${ }^{4}$ Before the session in which you run the game, you must prepare the spreadsheet for your needs, reflecting any refinements you made to the game and ensuring that the right number of rows exists in each worksheet.

The larger (and more talkative) your group, the longer each round will take. The simpler treatments, which we number Contract Period 1 and 2, will be relatively fast. Contract Periods 3 and 4, which respectively introduce Harvest Uncertainty and an Auction mechanism, take a bit longer. The treatments that require you to structure participants into communities (Contract Periods 5 and 6), take the longest because the participants must interact with each other.

The spreadsheet we provide is configured with one each of the above-mentioned treatments by default; additional worksheet copies can be made to repeat a treatment, and if you want to skip a treatment, you can simply skip or delete a worksheet.

In our experience, a 30-40 participant group can complete an abbreviated 3-round version with Contract Periods 1, 2 and 4 in 30-40 minutes with a moderate amount of discussion. You

\footnotetext{
${ }^{4}$ If Excel is set to not automatically perform calculations, the spreadsheet will not work! You can find this setting: On a PC:

- 2003: Tools $>$ Options $>$ Calculation $>$ Calculation $>$ Automatic.

- 2007: Office button $>$ Excel options $>$ Formulas $>$ Workbook Calculation $>$ Automatic.

- 2010 and 2013: File $>$ Options $>$ Formulas $>$ Workbook Calculation $>$ Automatic. On a Mac:

- 2008: Excel Preferences > Calculation > Automatically.
} 
can add the treatments with community decision-making (Contract Periods 5 and 6) if you have at least 50 minutes, though it might require briefer discussions. A 75-minute session allows you to play all six treatments, followed by a short debriefing and discussion. Additional time would allow treatments to be repeated (which would be particularly fruitful for the community decision treatments) and would make room for more in-depth discussion. Discussion and reflection can also happen outside of the session, through written assignments or online interactions.

Next, we describe generally how to play the game. All of the steps that follow are summarized in the Instructor How-To (Appendix III), which is a standalone document.

In advance of the session, decide which treatments to run and modify our materials as appropriate. Distribute the Instructions and Recording Sheet (Appendix I) and Handout (Appendix II) (and/or other readings) to participants if possible, along with any additional readings. Before the session, you can modify the spreadsheet to your needs, as well as the slides if you plan to use them.

When the session starts, provide students with printed instructions and cards that will give them their opportunity cost values. We use playing cards (ace through ten, with face cards removed and jokers retained, though you can use face cards in place of jokers) for these values. These values are not private information. Participants keep their values for the whole game. Each participant will also get an ID number that will be assigned as you record their responses in the spreadsheet; this will let you link together all decisions made by a given participant.

Before you start, you may want to emphasize a few points to participants. First, explain how many participants will be paid. Second, point out that each round is independent of other rounds; for example, in each new round, they get a new Farming Income and can change their contract decision. Third, note the importance of committing to their decisions by writing them 
down on the recording sheet (see Figure 1) in their instructions. This is to encourage them to treat this as a simultaneous game where they cannot change their decision once they hear what their peers have done. Fourth, urge them to be ready to respond quickly when it's time to record their decisions. Finally, point out that they should not jump ahead to future rounds but should wait for the group to move forward in lock step, and that certain payoff-relevant outcomes (like whether they are audited, or what the community decides) cannot be known in advance.

My decisions and my earnings (fill in the table below as the contract periods progress):

\begin{tabular}{|c|c|c|c|c|c|c|c|c|c|c|}
\hline $\mathbf{C P}$ & Conditions & $\begin{array}{c}\text { CHOOSE: } \\
\text { Bid }\end{array}$ & $\begin{array}{c}\text { CHOOSE: } \\
\text { REDD+? }\end{array}$ & $\begin{array}{l}\text { CHOOSE: } \\
\text { Fraud? }\end{array}$ & Audited? & $\begin{array}{c}\text { A } \\
\text { Farming } \\
\text { Income }\end{array}$ & $\begin{array}{c}\text { B } \\
\text { REDD+ } \\
\text { Payment }\end{array}$ & $\begin{array}{c}\text { C } \\
\text { Forest } \\
\text { Harvesting }\end{array}$ & $\begin{array}{c}\text { D } \\
\text { Policing, } \\
\text { Fines, etc. }\end{array}$ & $\begin{array}{l}\text { Earnings }= \\
A+B+C-D\end{array}$ \\
\hline 1 & Baseline & & $\mathrm{Y} \quad \mathrm{N}$ & & & $\$ 70$ & $\$$ & $\$$ & & $\$$ \\
\hline 2 & Fraud & & $\mathrm{Y} \quad \mathrm{N}$ & $\mathrm{Y}$ & $\mathrm{N}$ & $\$ 70$ & $\$$ & $\$$ & $\$$ & $\$$ \\
\hline 3 & Uncertainty & & $\mathrm{Y} \quad \mathrm{N}$ & & & $\$ 70$ & $\$$ & $\$$ & & $\$$ \\
\hline 4 & Auction & $\$$ & $\mathrm{Y} \quad \mathrm{N}$ & & & $\$ 70$ & $\$$ & $\$$ & & $\$$ \\
\hline 5 & Community & & $\mathrm{Y} \quad \mathrm{N}$ & & & $\$ 70$ & $\$$ & $\$$ & & $\$$ \\
\hline \multirow[t]{2}{*}{6} & Comm + Fraud & & $\mathrm{Y} \quad \mathrm{N}$ & $\mathrm{N}$ & $\mathrm{N}$ & $\$ 70$ & $\$$ & $\$$ & $\$$ & $\$$ \\
\hline & & & & & & & & TOTAL & $\$$ & $\$$ \\
\hline
\end{tabular}

Figure 1: Participant Decision Recording Sheet

At the start of each round, summarize the high points of the current treatment (on the board or using slides). Then give participants time to make their decisions. For each round except the Auction, the participant should circle $\mathrm{Y}$ (for adopting the REDD+ contract) or N (for not adopting) on her sheet so she is committed to her decision before she hears others' choices.

Then go around the room and have each student verbally report her decision. Move through the room in a systematic pattern to collect their decisions (e.g., row by row). Since the ID numbers exist only for recording purposes, as you collect the first round's decisions tell participants to record the ID number they have been assigned, and use the ID numbers in later rounds to ensure that you are putting each decision in the right row. 
If you are concerned about ensuring relatively simultaneous decisions, for treatments other than the Auction, you can give each participant a green and a brown piece of paper. When it's time to announce their decisions, each holds up the green if they choose to adopt REDD+ and brown if they do not. We have not tried this, but imagine that it could result in some mirth as people try to change their decisions and peers monitor and enforce the rule that they cannot.

Record choices in the REDD + column of the worksheet as "1" for those adopting REDD + (and blank for those not adopting), as shown in Figure 2. In the first round, you will also record their harvest value cards.

\begin{tabular}{|c|c|c|c|c|c|c|c|c|c|}
\hline ID & Harv Val & REDD+? & Add'I & Harvest? & Farm Inc & REDD+ Pmnts & Frst Hrvst & Earnings & Missed meal? \\
\hline $1 \mathrm{~J}$ & & 1 & $1 \mathrm{NOT}$ & 0 & $\$ 70$ & $\$ 50$ & $\$ 0$ & $\$ 120$ & FALSE \\
\hline 2 & 4 & & ADDL & 0 & $\$ 70$ & $\$ 50$ & $\$ 0$ & $\$ 120$ & FALSE \\
\hline 3 & 5 & 1 & ADDL & 0 & $\$ 70$ & $\$ 50$ & $\$ 0$ & $\$ 120$ & FALSE \\
\hline 4 & 10 & & & 1 & $\$ 70$ & $\$ 0$ & $\$ 100$ & $\$ 170$ & FALSE \\
\hline 5 & 2 & 1 & ADDL & 0 & $\$ 70$ & $\$ 50$ & $\$ 0$ & $\$ 120$ & FALSE \\
\hline 6 & 7 & & & 1 & $\$ 70$ & $\$ 0$ & $\$ 70$ & $\$ 140$ & FALSE \\
\hline 7 & 3 & 1 & ADDL & 0 & $\$ 70$ & $\$ 50$ & $\$ 0$ & $\$ 120$ & FALSE \\
\hline 8 & 9 & & & 1 & $\$ 70$ & $\$ 0$ & $\$ 90$ & $\$ 160$ & FALSE \\
\hline 9 & 3 & 1 & ADDL & 0 & $\$ 70$ & $\$ 50$ & $\$ 0$ & $\$ 120$ & FALSE \\
\hline $10 \mathrm{~J}$ & & 1 & L NOT & 0 & $\$ 70$ & $\$ 50$ & $\$ 0$ & $\$ 120$ & FALSE \\
\hline $11 \mathrm{~J}$ & & 1 & L NOT & 0 & $\$ 70$ & $\$ 50$ & $\$ 0$ & $\$ 120$ & FALSE \\
\hline $12 \mathrm{~J}$ & & 1 & L NOT & 0 & $\$ 70$ & $\$ 50$ & $\$ 0$ & $\$ 120$ & FALSE \\
\hline 13 & 1 & & ADDL & 0 & $\$ 70$ & $\$ 50$ & $\$ 0$ & $\$ 120$ & FALSE \\
\hline $14 \mathrm{~J}$ & & 1 & L NOT & 0 & $\$ 70$ & $\$ 50$ & $\$ 0$ & $\$ 120$ & FALSE \\
\hline 15 & 4 & 1 & ADDL & 0 & $\$ 70$ & $\$ 50$ & $\$ 0$ & $\$ 120$ & FALSE \\
\hline 16 & 6 & & & 1 & $\$ 70$ & $\$ 0$ & $\$ 60$ & $\$ 130$ & FALSE \\
\hline 17 & 4 & & ADDL & 0 & $\$ 70$ & $\$ 50$ & $\$ 0$ & $\$ 120$ & FALSE \\
\hline 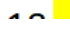 & & . & י & - & 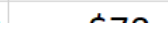 & 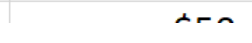 & an & san & ras \\
\hline
\end{tabular}

Figure 2: Excel Worksheet to Record Decisions (First Round)

Before moving onto the next treatment, ask the participants to briefly reflect on what happened and compare the outcomes from the current treatment with the previous treatments. This can lay the groundwork for a richer discussion at the end of the game. 


\section{After the Game}

Once decision-making is complete, and before you start a deeper discussion, show the participants a big picture view of what happened during the game and how they fared, and, if possible, pay one or more participants. The "summaries" worksheet (see Figure 3) shows summary information broken down by participant and by round; you can project it at any time, but it is particularly useful when the game is over.

\begin{tabular}{|c|c|c|c|c|c|c|}
\hline ID & 1-Baseline & 2-Fraud & 4-Auction & 5-Community & Total & Dollars \\
\hline 1 & $\$ 120$ & $\$ 120$ & $\$ 119$ & $\$ 115$ & $\$ 474$ & $\$ 4.74$ \\
\hline 2 & $\$ 120$ & $\$ 120$ & $\$ 119$ & $\$ 110$ & $\$ 469$ & $\$ 4.69$ \\
\hline 3 & $\$ 120$ & $\$ 120$ & $\$ 120$ & $\$ 121$ & $\$ 481$ & $\$ 4.81$ \\
\hline 4 & $\$ 170$ & $\$ 170$ & $\$ 170$ & $\$ 170$ & $\$ 680$ & $\$ 6.80$ \\
\hline 5 & $\$ 120$ & $\$ 0$ & $\$ 119$ & $\$ 120$ & $\$ 359$ & $\$ 3.59$ \\
\hline 6 & $\$ 140$ & $\$ 140$ & $\$ 140$ & $\$ 140$ & $\$ 560$ & $\$ 5.60$ \\
\hline 7 & $\$ 120$ & $\$ 120$ & $\$ 119$ & $\$ 110$ & $\$ 469$ & $\$ 4.69$ \\
\hline 8 & $\$ 160$ & $\$ 160$ & $\$ 160$ & $\$ 140$ & $\$ 620$ & $\$ 6.20$ \\
\hline 9 & $\$ 120$ & $\$ 120$ & $\$ 119$ & $\$ 100$ & $\$ 459$ & $\$ 4.59$ \\
\hline 10 & $\$ 120$ & $\$ 120$ & $\$ 119$ & $\$ 120$ & $\$ 479$ & $\$ 4.79$ \\
\hline 11 & $\$ 120$ & $\$ 120$ & $\$ 119$ & $\$ 70$ & $\$ 429$ & $\$ 4.29$ \\
\hline$\hat{i}$ & ta & Man & $21{ }^{1}$ & tasn & $A n \rightarrow n$ & 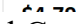 \\
\hline
\end{tabular}

\begin{tabular}{|l|r|rrr|r|} 
& CP1-Baseline & CP2-Fraud & CP4-Auction & CP5-Community \\
\hline Number of households & 29 & 29 & 29 & 29 \\
\hline Number of REDD+ contracts & 18 & 22 & 14 & 17 \\
\hline Number of fraudulent contracts & 0 & 6 & 0 & 0 \\
\hline Number of hungry families & 0 & 3 & 0 & 1 \\
\hline Number of non-additional contracts & 7 & 7 & 7 & 6 \\
\hline Number of additional contracts & 11 & 15 & 7 & 11 \\
\hline Conservation expenditures & $\$ 900$ & $\$ 950$ & $\$ 686$ & $\$ 850$ \\
\hline Median bid & & & $\$ 49$ & \\
\hline Auction REDD+ payment & & & $\$ 49$ & \\
\hline Person chosen for payment & & & & \\
\hline
\end{tabular}

Note: in this example, the Uncertainty and Community+Fraud treatments were not played and thus were deleted.

Figure 3: Worksheet Summarizing Game Outcomes

We suggest that you randomly pick one or a few students to be paid. The "summaries" sheet of the Excel workbook has a built-in tool for doing this; at the bottom of Figure 3, you can see the "Person chosen for payment" cell indicates participant 22 was paid in that play of the game. We usually pay participants in cash (you can use a payment app to avoid having to carry the relevant cash and change to class), but you could instead use extra credit (if you are playing the game with a class). Alternatives abound: for example, you could donate an amount proportional to class earnings to a land conservation charity chosen by the participants. You might also be concerned about fairness in potential earnings, as people who randomly got higher cards have larger possible earnings; if this is a problem for you, you could make payments that are proportional to the ratio of earnings to possible earnings. 
Allow the participants to keep their instructions and recording sheets. Share the completed spreadsheet with them (e.g., through a course website).

\section{Leading Discussions about the Game}

Because this game covers many topics, discussions can be wide-ranging, and should obviously be tuned to the topics of greatest interest to you and the participants. We will outline here some examples of discussion topics we think are particularly interesting.

First, a general discussion about payments for ecosystem services schemes and their functioning can be fruitful in helping the participants link what they found in the game with concepts they have encountered in broader or academic material. You can discuss the global public goods provided by forest preservation, and talk about how payments can internalize positive externalities. You can ask participants to draw the distinction between efficiency and cost-effectiveness in this context. In discussing cost-effectiveness, link the forest preservation costs in the game to concepts of opportunity cost and, if it is appropriate for this group, to the concept of abatement costs. It may be fruitful to discuss why opportunity costs might vary across households in this context.

This can also be an opportunity to discuss cost-effectiveness in fighting climate change. The McKinsey \& Company (2009) carbon marginal abatement cost curve can be a good tool for this: you can discuss the whole range of both positive and negative marginal costs, and look at where avoided deforestation lies in the graph, noting that estimates of these costs have changed in the decade since that report was published. Cost-effectiveness can seem like a nit-picky technical detail, particularly to students, so this is also an opportunity to consider nuances like how the pursuit of cost-effectiveness might decrease or increase inequality. 
We would argue that additionality almost always deserves significant discussion time, since it is a difficult topic to understand (because it revolves around an invisible counterfactual) but one on which economics offers a clear window. Further, it is important because it can degrade the efficacy of (and the public's faith in) environmental initiatives. This issue is not unique to REDD+; you can make parallels to applications as similar as the U.S. Conservation Reserve Program and as distant as social policies like paying kids for grades in school. We use forests owned by our institutions' as examples of preservation that is likely non-additional. You can explore the tension between the goals of cost-effectiveness and additionality. Costeffectiveness requires achieving a policy objective in the cheapest possible way; additionality requires that payments target actions that would not have occurred in the absence of payments. Non-additional units are, by definition, the cheapest units to enroll in a program, so an uncareful quest for cost-effectiveness could yield serious additionality failures. You can point out that additionality failures, while reducing the effectiveness of the program, don't necessarily hurt efficiency (in a Pareto sense) relative to a no-policy baseline since (again by definition) they represent a transfer that doesn't change behavior. In other words, payments to non-additional units don't distort the outcomes for those units and thus create inefficiency as a classic Econ 101 subsidy might. However, such payments obviously waste money that could yield social benefits if they were used to preserve additional parcels, so efficiency is worse than a perfect-policy counterfactual. Additionality failures are a pernicious issue that can reduce the efficacy of payments for ecosystem service programs, and fail to produce efficient outcomes if they are relied on to provide conservation.

You could couple a discussion of additionality with a discussion of another feature that is not covered in our game but can also sap away the effectiveness of a program like REDD+: 
leakage, or the tendency for program enrollment of some parcels to cause, through market channels, increased exploitation on other unenrolled parcels, so that net conservation is less than a headline assessment of enrollment numbers would imply.

Discussions about the costs and benefits of preserving forests can link to broader issues about forests and other common pool resources. If you are using the game in a class with a forestry economics module, you can link the opportunity cost in the game to forestry model parameters. More generally, you can connect REDD + contract payments to the social benefits of preservation, discussing what those benefits are and at what geographic level (local, national, and global) they accrue; as noted above, this can be a discussion about internalizing an externality and monetizing a nonmarket commodity (environmental quality), and the equity and efficiency implications of doing so. If your participants are interested in international policy, you can discuss the policy history of REDD+, which illustrates some interesting pitfalls with regard to both efficiency and equity. You might highlight questions about what issues arise if the opportunity cost of preservation, or the difficulty in detecting contract violation, is correlated with the ecosystem services a forest area provides, and what implications these correlations have for policy.

Broader discussions of climate change and global climate policy are very relevant. In particular, many people are extremely skeptical about forest-based offsets, either in practical terms (do they yield the climate benefits promised?), with concerns about justice and exploitation of people in developing countries, or with ethical concerns about "buying out" of the problem rather than reducing greenhouse gases at home. We encourage participants to confront these issues head on and to reflect on whether these are per se features of these programs or whether they can be avoided with strong policy design. Different people will come to different 
conclusions, and we emphasize to our participants that even if they believe that this form of offsetting is inherently problematic, the game will help them understand the mechanics of offsets and the specifics of some of the attractive and unattractive features of how they can be used.

Verifiability is a deeply important issue in offset provision in general, and in forest-based offsets in particular, and the game easily tees up discussions about contract fraud and monitoring uses. We do, however, urge some caution when you lead these discussions. Because cheating can be "fun" in a classroom context, participants may focus a lot of their energy and attention on fraud as a likely outcome. While monitoring is important, and while you can make many interesting points about how to improve adherence to contracts (e.g., discuss the role that satellite imagery can play in enforcement), it's important that participants not come away from the game thinking that low-income people in developing countries are inherently fraudsters. On the contrary, as highlighted by Elinor Ostrom's seminal work (see Ostrom (2010) for a summary), communities in developing countries have a plethora of informal and formal rules, enforcement mechanisms, and governance structures for managing common pool resources and preventing fraud. A game can lead to a discussion of community governance and informal institutions and the conditions under which community governance tends to succeed, including the role of nonpecuniary incentives. It is also useful to discuss the possibility of power imbalances within countries that are involved with such programs: if those who depend on the forest for livelihoods do not have agency in decisions about REDD+ contracts, they can be made unambiguously worse off if REDD+ payments are captured by elites. You can make parallels, as well, to other non-forest-related common pool resource management problems, such as ocean fisheries, fertilizer use, and the overuse of pesticides and antibiotics. 
Risk and uncertainty are important features of this game and of the settings that the game is meant to mimic. You can use the Uncertainty treatment to discuss risk neutrality and risk aversion, and the way in which conservation contracts can act as insurance in some cases, which may be especially attractive as climate change increases the variability of conditions people are exposed to. You could discuss the role that a community could play, instead, in providing mutual insurance against these idiosyncratic shocks, and how that insurance would become less effective if shocks were more systemic as they will be as climate change progresses. The fraud treatments provide additional opportunity to discuss risk and uncertainty in the context of a model of rational crime and deterrence (Becker, 1968); indeed, in the Community Contract + Fraud treatment, participants face ambiguity (also known as Knightian uncertainty) because they don't know the odds with which community members will choose to commit fraud.

Various forms of social and non-pecuniary preferences are an important feature of this decision-making process, in the game as in the real-life setting it emulates, as well. Some people may have altruistic or warm glow (Andreoni, 1995) preferences about providing public goods. Some people might have a taste for environmental conservation. Others may have an interest in maintaining a reputation or self-image, or conforming to a social norm. In the community treatments, there may be questions of persuasion and negotiation. Some people might have an aversion to lying. For all of these topics, you can make analogies to other contexts where these preferences may play out, including crime and deterrence, voluntary environmental choices like driving less, and academic honesty. 


\section{Student Feedback and Evidence of Pedagogical Effectiveness}

In this section, we report outcomes from playing the game in environmental economics classes at two liberal arts colleges and a research university, after which we performed informal surveys with students, as well as at capacity-building training workshops for mid-career officials and professionals in a developing country. The academic settings in which the game were played were: School A, a liberal arts school, a two-section environmental economics class in spring of 2017 with 66 total students (from which we received 48 survey responses); School B, a liberal arts school, an environmental economics class in spring of 2017 with 35 students (from which we received 28 responses); and School C, a research university, a class on conservation in spring 2019 with 24 students with limited economics background (from which we received 16 responses). We were not able to survey the capacity-building training participants, who played the game in summer 2016, but we provide reflections on their experience with the game. We conducted the game ourselves at School A, School B, and in the policymaker training. At School C, the game was conducted by an instructor other than the authors.

First, when asked general questions about the whether the game was a good use of class time and whether it helped their comprehension, as shown in Table 1, nearly all of students responded affirmatively.

Table 1: Participant Evaluation of Game Value

\begin{tabular}{|c|c|c|}
\hline & $\begin{array}{l}\text { Was the game a good } \\
\text { use of class time? }\end{array}$ & $\begin{array}{l}\text { Did the game help you understand deforestation and } \\
\text { how schemes like REDD + can fight it? }\end{array}$ \\
\hline School A & $100 \%$ & $\mathrm{~N} / \mathrm{A}$ \\
\hline School B & $96 \%$ & $93 \%$ \\
\hline School C & $94 \%$ & $88 \%$ \\
\hline \multicolumn{3}{|c|}{ Cells contain the percent of post-game survey respondents who said "Yes" to the question. } \\
\hline
\end{tabular}


was reflected in the game. As seen in Table 2, the majority of participants agreed that these concepts were reflected in their experience with the game, and some of the topics (like fraud, community governance, and trust and cooperation) had even stronger recognition. Some topics are naturally harder to communicate; for example, we do not find it surprising that additionality was still challenging for some participants.

Table 2: Participant Recognition of Topics in the Game

\begin{tabular}{lcc}
\hline & \multicolumn{2}{c}{ Percent Agreed or Strongly Agreed } \\
Topic & School A & School C \\
\hline Additionality & $54 \%$ & $69 \%$ \\
Cost-effective abatement & $73 \%$ & $69 \%$ \\
Verifiability & $83 \%$ & $50 \%$ \\
Leakage / fraud & $98 \%$ & $71 \%$ \\
Community governance & $100 \%$ & $81 \%$ \\
Trust and cooperation (in community & $94 \%$ & $94 \%$ \\
$\quad$ resource management) & & \\
\hline
\end{tabular}

Note: Cells contain percentages of responses to the question, "Did you understand how each of these concepts were incorporated into the game?" that were "Strongly agree" or "Agree" for the named topic.

In the survey, participants had the opportunity to express lessons from the game in their own words. When asked (in an open-ended question) what their "takeaways" were from the game, participants at School A mentioned "REDD" and "payment for ecosystem services" 48 times, "fraud" 21 times, and "community" and "payment" 12 times each; at School B, participants mentioned "REDD+" 20 times, "deforestation" and "PES" 8 times, and "fraud" 6 times. At School A, a participant said their takeaways were "the challenges involved in REDD programs. For example, how do you ensure that REDD will actually reduce deforestation that would have happened and how do you make sure there is no illegal logging and people who get the benefit of cutting down trees and joining REDD.” A student at School B said they learned "That in a theoretical world, REDD + can be a cost effective way to achieve a particular level of abatement." Another said that key points to consider in implementing a program like this are: “1. 
Need to consider additionality -- how much is the program actually adding compared to the baseline. 2. Need a method of verifying and encouraging participants to follow their contracts. 3. Best to have a method (like the auction) to determine individual values for the contract to increase efficiency of the program."

The instructor from School C said in a personal communication to the authors that the game helped link multiple topics covered in the class and that "Both the individual decisions and the group/community decisions led to some fun conversations and many "Aha!" moments in which people realized how things fit together ... And I really liked the part about identifying the additionality — I could tell that they hadn't really gotten that in my presentation of the material earlier on. Of course, I emphasize enforcement costs throughout the course - but it was fun to see who was caught and who got lucky."

Finally, one of the authors used the game multiple times in capacity building trainings of mid-career professionals in government, $\mathrm{NGO}$, and the private sector in a developing country. The training sessions were part of two-day workshops with 25-35 participants. In each workshop, 90 minutes was devoted to this game. The participants included career officials working to create policies to regulate deforestation. Again, the feedback, while informal, was very positive, with multiple participants commenting how the game helped them internalize the decision-making context of rural households engaged in deforestation and how such households might react to different policy instruments. 


\section{Possible Extensions and Modifications}

This game provides flexibility to allow instructors to emphasize the topics and features that are most relevant to the lessons they wish to convey. The materials we share are fully editable to allow easy customization.

In the spreadsheet, you can create duplicate worksheets to repeat treatments more than once, or you can skip treatments by deleting or ignoring the relevant worksheets and deleting the relevant columns in the "summaries" worksheet. You can also modify parameters if you want to shift the incentives of the game by editing cells in the "params" sheet. For example, you can make an audit more or less likely, or the punishment for fraud larger or smaller.

To fine-tune the game to issues more central to your participant group or your local area, you can reframe the context without changing incentives by simply editing the text in the instructions. For example, instead of being rural households extracting firewood from a communal forest, you could frame the game as fishers harvesting from an open access fishery or farmers in the southwest U.S. extracting groundwater from a common groundwater reservoir. The core structure of the game applies to any situation in which a community of agents receive heterogeneous benefits from extracting some resource that also provides ecosystem service benefits to those outside the community of extractors.

You could create entirely new treatments to explore other ideas or to build up other concepts. In what follows, we list some example ideas, but as the spreadsheet and instructions are fully editable, you are only constrained by your imagination (and your Excel skills).

You can make combinations of the treatments we provide. For example, an auction mechanism or uncertain harvest return can be built into any of the other treatments. 
If you have more time available and especially if you have participants who may struggle to understand the incentive system, you can start with a " 0 "th" round in which there is no REDD+ payment. In this treatment, profit-maximizing participants with cards other than the joker (or face cards) should always choose to harvest. This will establish the extent of deforestation that can be avoided solely through nonpecuniary preferences of the participants (e.g., a taste for conservation). This will also provide an absolute baseline to which to compare the other treatments' outcomes.

You can create treatments that explore more elements of enforcement and penalties. You can vary parameters to show how participants change their fraud behavior as you change the likelihood that fraud is detected. You can create a peer enforcement treatment in which participants have the opportunity to audit and/or punish each other. (If you want an audit to be necessary to detect fraud, you'll need to find a way to hide the identity of decision-makers, or you'll need to video mute the spreadsheet at strategic times.) You can make peer reporting costly or remunerative.

You can modify any of the treatments to incorporate realistic policy features; for example, you could add a government budget to the auction treatment so that bids will be accepted only up to a maximum total payout.

You can also add realism on many dimensions of the model of the economic situation. For example, the game we present assumes that there is no firewood market. If you want to demonstrate implications of market interconnections, you can introduce a perfectly competitive firewood market and vary the price of the firewood to see how that changes harvest, either as a new treatment or as a modification of the existing treatments. If you let reduced harvest from REDD + adoption drive up the price of firewood, then you can directly demonstrate leakage. 
The uncertainty treatment can be extended or expanded into more treatments. One possibility is to link the uncertainty to the impact of climate change on agriculture: the households' farming income could be subject to uncertainty. While this doesn't change the marginal incentive to take up a contract, if the participants take the "missed meal" rule seriously, then the risk of crossing that threshold is increased by differences in the farming income. You can allow participants to insure each other, or to buy insurance on an insurance market. You can allow the REDD+ payments to explicitly provide insurance in the sense of being larger in years when farming income is lower. This feeds into a discussion about uncertainty, risk, cropinsurance, and climate change into the game. ${ }^{5}$

You could add variation in farming income to represent different gradations of wealth endowment. This could be just exogenous variation that is fixed and random, or you could have random shocks hit farming income (in the way they hit harvest value in the Uncertainty treatment). You could also have take-up of a REDD+ contract carry a reduction in farming income; the way we have framed the game is like the situation in some African and South Asian countries where REDD+ would prevent piecemeal harvesting of the forest for firewood use, whereas in some other settings, like Brazil, REDD+ would prevent clearing of the forest for agriculture. This could be just a relabeling of the foregone forest harvest earnings as foregone farming earnings. As currently designed, none of these changes affect decisions at the margin because farming income does not change the returns from contract adoption; however, again, if

\footnotetext{
${ }^{5}$ For example, if you want to show how the REDD+ payments can act as insurance, you can add uncertainty (a mean-preserving spread) to the return to farming. You can do this by adding a "Realized Farming Income" column that differs from the "Farming Income" column by a random offset or multiplier. The shock can be created by a manual die-roll (e.g., you could roll a six-sided die; income is reduced by $\$ 30$ if a one is rolled, increased by $\$ 30$ if a six is rolled, and remains unchanged otherwise). Alternatively, you can use the rand() function in Excel; for example, you could create a multiplicative factor equal to (rand() times 0.4 minus 0.2 ), which generates a value from -0.2 to +0.2 . (If you use rand(), because the function recalculates each time you edit the spreadsheet, copy the realized numbers and the paste their values to make them permanent.)
} 
participants are attentive to the "missed meal" threshold, then discontinuously at that threshold, lower farming income could make them more risk averse, which might alter decisions.

\section{Conclusion}

Climate change and deforestation are immense global problems and they are attracting increasing concern. Some of the issues that arise in fighting them can be hard to grasp. Active pedagogy can be effective in transmitting complex topics, and classroom experiments or games can help participants internalize ideas as they make decisions in scenarios that mimic the real world. In this paper, we have presented a new interactive game that can be used in a variety of classroom and training settings to explore ideas about forest management, incentive-based conservation, community decision-making, and much more through the lens of the United Nations REDD+ anti-deforestation program. The game is flexible and fully customizable, and we provide all of the tools you need to engage your participants with these concepts. We hope you enjoy the game and find it a fruitful learning experience! 


\section{References}

Agrawal, A., Chhatre, A., Hardin, R., 2008. Changing governance of the world's forests. Science, 320(5882), 1460-1462.

Alix-Garcia, J.M., Shapiro, E.N., Sims, K.R.E., 2012. Forest conservation and slippage: Evidence from Mexico's national payments for ecosystem services program. Land Economics, 88(4), 613-638.

Andreoni, J., 1995. Warm-Glow versus Cold-Prickle: The Effects of Positive and Negative Framing on Cooperation in Experiments. Quarterly Journal of Economics, 110(1), 1-21.

Angelsen, A., 2008, Moving ahead with REDD: issues, options and implications. Cifor.

Angelsen, A., 2009, Realising REDD+: National strategy and policy options. Cifor.

Baker, K., Baylis, K., Bull, G.Q., Barichello, R., 2019. Are non-market values important to smallholders' afforestation decisions? A psychometric segmentation and its implications for afforestation programs. Forest Policy and Economics, 100, 1-13.

Balooni, K., Lund, J.F., 2014. Forest rights: the hard currency of REDD+. Conservation Letters, 7(3), 278-284.

Bastin, J.-F., Finegold, Y., Garcia, C., Mollicone, D., Rezende, M., Routh, D., Zohner, C.M., Crowther, T.W., 2019. The global tree restoration potential. Science, 365(6448), 76-79.

Baylis, K., Honey-Rosés, J., Börner, J., Corbera, E., Ezzine-de-Blas, D., Ferraro, P.J., Lapeyre, R., Persson, U.M., Pfaff, A., Wunder, S., 2016. Mainstreaming impact evaluation in nature conservation. Conservation Letters, 9(1), 58-64.

Becker, G.S., 1968. Crime and Punishment: An Economic Approach. The Journal of Political Economy, 76(2), 169-217.

Bluffstone, R., 2013. Economics of REDD+ and community forestry. Journal of Forest and Livelihood.

Bluffstone, R., Robinson, E., Guthiga, P., 2013. REDD+ and community-controlled forests in low-income countries: Any hope for a linkage? Ecological economics, 87, 43-52.

Brown, P., 1998. Climate, biodiversity, and forests. World Resources Institute, Washington, DC.

Chao, S., 2012, Forest peoples: numbers across the world. Forest Peoples Programme Moretonin-Marsh.

Chhatre, A., Agrawal, A., 2009. Trade-offs and synergies between carbon storage and livelihood benefits from forest commons. Proceedings of the national Academy of sciences, 106(42), 17667-17670.

Economist, 2010, Keeping it in the Community. The Economics.

Engel, S., 2016. The devil in the detail: A practical guide on designing payments for environmental services. International Review of Environmental and Resource Economics, 9(1-2), 131-177.

Engel, S., Pagiola, S., Wunder, S., 2008. Designing payments for environmental services in theory and practice: An overview of the issues. Ecological economics, 65(4), 663-674.

Griscom, B.W., Adams, J., Ellis, P.W., Houghton, R.A., Lomax, G., Miteva, D.A., Schlesinger, W.H., Shoch, D., Siikamäki, J.V., Smith, P., 2017. Natural climate solutions. Proceedings of the national Academy of sciences, 114(44), 11645-11650.

Harrison, M.E., Paoli, G.D., 2012. Managing the risk of biodiversity leakage from prioritising REDD+ in the most carbon-rich forests: the case study of peat-swamp forests in Kalimantan, Indonesia. Tropical Conservation Science, 5(4), 426-433. 
Holt, C.A., 1999. Teaching Economics with Classroom Experiments: A Symposium. Southern Economic Journal, 65(3), 603-610.

Honey-Rosés, J., López-García, J., Rendón-Salinas, E., Peralta-Higuera, A., Galindo-Leal, C., 2009. To pay or not to pay? Monitoring performance and enforcing conditionality when paying for forest conservation in Mexico. Environmental Conservation, 36(2), 120-128.

Honey-Rosés, J., Baylis, K., Ramirez, M.I., 2011. A spatially explicit estimate of avoided forest loss. Conservation biology, 25(5), 1032-1043.

IPCC, 2014. IPCC, 2014: climate change 2014: synthesis report. Contribution of Working Groups I. II and III to the Fifth Assessment Report of the intergovernmental panel on Climate Change. IPCC, Geneva, Switzerland, 151.

Jayachandran, S., De Laat, J., Lambin, E.F., Stanton, C.Y., Audy, R., Thomas, N.E., 2017. Cash for carbon: A randomized trial of payments for ecosystem services to reduce deforestation. Science, 357(6348), 267-273.

Joseph, S., Herold, M., Sunderlin, W.D., Verchot, L.V., 2013. REDD+ readiness: early insights on monitoring, reporting and verification systems of project developers. Environmental Research Letters, 8(3), 034038.

Lubowski, R.N., Rose, S.K., 2013. The Potential for REDD+: Key Economic Modeling Insights and Issues. Review of Environmental Economics and Policy, 7(1), 67-90.

McKenney, D.W., Yemshanov, D., Fox, G., Ramlal, E., 2004. Cost estimates for carbon sequestration from fast growing poplar plantations in Canada. Forest Policy and Economics, 6(3-4), 345-358.

McKinsey \& Company, 2009. Pathways to a low-carbon economy: Version 2 of the global greenhouse gas abatement cost curve.

Millennium Ecosystem Assessment, 2005, Millennium Ecosystem Assessment General Synthesis Report: Ecosystems and Human Well-being. Millennium Ecosystem Assessment.

OECD, I.E.A., 2017. World Energy Outlook - Special Report on Energy Access. World Energy Outlook.

Olander, L.P., Gibbs, H.K., Steininger, M., Swenson, J.J., Murray, B.C., 2008. Reference scenarios for deforestation and forest degradation in support of REDD: a review of data and methods. Environmental Research Letters, 3(2), 025011.

Ostrom, E., 1990, Governing the commons: The evolution of institutions for collective action. Cambridge university press.

Ostrom, E., 2010. Beyond markets and states: polycentric governance of complex economic systems. American economic review, 100(3), 641-672.

Pan, Y., Birdsey, R.A., Fang, J., Houghton, R., Kauppi, P.E., Kurz, W.A., Phillips, O.L., Shvidenko, A., Lewis, S.L., Canadell, J.G., 2011. A large and persistent carbon sink in the world's forests. Science, 333(6045), 988-993.

Pattanayak, S.K., Wunder, S., Ferraro, P.J., 2010. Show Me the Money: Do Payments Supply Environmental Services in Developing Countries? Review of Environmental Economics and Policy, 4(2), 254-274.

Popkin, G., 2019, How much can forests fight climate change. Nature, pp. 280-282.

R. Chazdon, P.B., 2019, Restoring forests as a means to many ends. Science, pp. 24-25.

Rakatama, A., Pandit, R., Ma, C., Iftekhar, S., 2017. The costs and benefits of REDD+: A review of the literature. Forest Policy and Economics, 75, 103-111. 
Saatchi, S.S., Harris, N.L., Brown, S., Lefsky, M., Mitchard, E.T.A., Salas, W., Zutta, B.R., Buermann, W., Lewis, S.L., Hagen, S., 2011. Benchmark map of forest carbon stocks in tropical regions across three continents. Proceedings of the national Academy of sciences, 108(24), 9899-9904.

Salas, P.C., Roe, B.E., Sohngen, B., 2018. Additionality when redd contracts must be selfenforcing. Environmental and resource economics, 69(1), 195-215.

Shah, P., Baylis, K., 2015. Evaluating heterogeneous conservation effects of forest protection in Indonesia. PloS one, 10(6), e0124872.

Sills, E.O., Atmadja, S.S., de Sassi, C., Duchelle, A.E., Kweka, D.L., Resosudarmo, I.A.P., Sunderlin, W.D., 2014, REDD+ on the ground: A case book of subnational initiatives across the globe. Cifor.

Sims, K.R.E., Alix-Garcia, J.M., 2017. Parks versus PES: Evaluating direct and incentive-based land conservation in Mexico. Journal of Environmental Economics and Management, 86, 8-28.

Sloan, S., Pelletier, J., 2012. How accurately may we project tropical forest-cover change? A validation of a forward-looking baseline for REDD. Global Environmental Change, 22(2), 440-453.

Song, L., 2019. An (Even More) Inconvenient Truth: Why Carbon Credits for Forest Preservation May Be Worse than Nothing, ProPublica.

Springate-Baginski, O., Wollenberg, E., 2010, REDD, forest governance and rural livelihoods: the emerging agenda. CIFOR.

Stavins, R.N., Richards, K.R., 2005. The cost of U. S. forest-based carbon sequestration. Pew Center on Global Climate Change. 52, 52.

Stern, 2006. Stern Review: The economics of climate change. London, England: HM Treasury.

Toni, F., 2011. Decentralization and REDD+ in Brazil. Forests, 2(1), 66-85.

UN-REDD, 2015. Regions and Countries Overview, http://www.unredd.net/index.php?option=com_unregions\&view $=$ overview\&Itemid=495\#

UNFCCC, 2011. Fact Sheet: Reducing Emissions from Deforestation in Developing Countries.

Van der Werf, G.R., Morton, D.C., DeFries, R.S., Olivier, J.G.J., Kasibhatla, P.S., Jackson, R.B., Collatz, G.J., Randerson, J.T., 2009. CO 2 emissions from forest loss. Nature geoscience, 2(11), 737.

Wunder, S., 2005. Payments for environmental services: some nuts and bolts. 


\section{Appendix I: Instructions and Recording Sheet}

\section{“Money Growing on Trees" Instructions}

\section{Overview:}

You are a household in the beautiful, but low-income, tropical country of Ephoria. You live in a rural area on the margin of a forest. There used to be much more forest and many fewer people living in this area, but expansion of urban areas and agriculture over the last few decades has put a bit of a crunch on your local area (even though it is not geographically close to urban centers).

You and the members of your small, traditional community support yourselves primarily through small-scale agriculture in your garden plots (subsistence farming) and from harvesting wood and non-timber forest products such as fruits and nuts, medicinal plants, fish and game, and bark and fibers from the local forest. You use the wood you harvest from the forest for cooking and heating, but this harvest contributes to climate change and deforestation. If you don't harvest wood and materials from the forest, you either do without or buy replacement food and fuel on the market.

You were randomly given a playing card at the start of this session. The number on this card (110 , or Joker or a face card) indicates the benefits your family gets when you harvest from the forest. Harvest values vary for many reasons: different parts of the forest yield different harvestable goods, some households have more family members (e.g., children or aging relatives) to support, and some households have better access to other opportunities to earn income, for example. If you got a number card, then your value for harvesting is usually $\$ 10$ times the number on your card. If you got a Joker or a face card, then your value for harvesting is $\$ 0$. Note the forest is commonly owned, but is so large that your harvest doesn't affect that of your community members right now, and vice versa.

To fight deforestation and raise revenue, policymakers in your country have decided to experiment with payments for ecosystem service (PES) schemes through the UN's REDD+ program. Local households and/or communities will make contracts with the country's REDD+ Secretariat. Then people or firms outside the country, typically in developed countries, will "buy" units of avoided deforestation from Ephoria to offset their greenhouse gas emissions.

In this session, we will play through contract periods of several different REDD+ situations. In each period, you must make a decision: whether to enter into a REDD+ contract, which will prohibit you from harvesting wood the forest. You may have another decision to make as well. You will have earnings that will depend on your choices, in some cases the choices of other households, and in some cases on chance. However, if your earnings are not at least $\$ 75$ in a period, then you and your family are unable to eat for a day, which means that any babies in the family will cry all night and your life will be pretty unpleasant. 
At the end of the session, we will pick one or more participants who will earn actual money equal to the sum of their earnings in all rounds divided by $\$ 100$. Since real money is on the line, you should play close attention and be sure to make the decisions that you really want to make!

\section{Your earnings:}

In each contract period, your earnings are:

Earnings $=$ Farming Income + REDD + Payments + Forest Harvesting $-($ Policing or Fines $)$

Farming Income: this comes from your subsistence farming on the plot of land in your yard. Except when otherwise noted, this is $\$ 70$.

REDD+ Payments: if you enter into a REDD+ contract, you get a REDD+ payment from the REDD+ market. Except when otherwise noted, this is \$50. You can think of this as including both the money from REDD + and any additional value (e.g., labor earnings) you get from the time that has been freed up that you would have otherwise spent harvesting from the forest.

Forest Harvesting: if you enter into a REDD+ contract, you agree not to harvest wood from the forest. If you don't enter into a REDD+ contract, except as noted, you earn an amount from harvesting equal to $\$ 10$ times the number on the card you were dealt or $\$ 0$ if you got a Joker or face card.

(Policing or Fines): these do not apply in periods in which fraud is impossible. When fraud is possible, you may incur additional costs from fines or to finance policing.

\section{Contract Period 1: Baseline}

Earnings and decisions are exactly as described above. If you decide to enter into a REDD+ contract, you must not harvest wood. (All REDD+ parcels are audited and monitored to ensure zero harvesting; this is true in all contract periods except as otherwise noted.)

\section{Contract Period 2: Baseline + Fraud}

Everything is as in Baseline except that you can commit fraud by entering into a REDD+ contract and then harvesting wood anyway. Each parcel in a REDD+ contract will be audited with a $25 \%$ likelihood. If you are audited and found to be harvesting, you will not receive your REDD+ payment and you will have to give up your harvest, and you will be fined $\$ 70$.

\section{Contract Period 3: Harvest Uncertainty}

There is a plague of locusts this year, so the forest is very rich in some areas but terrible in others! Each household that tries to harvest has a 50\% chance of getting \$20 times the number on their card and a 50\% chance of getting $\$ 0$. The plague will strike after you have decided whether to participate in REDD+. Otherwise the period proceeds like Baseline. 


\section{Contract Period 4: Auction}

Instead of declaring whether to enter into a REDD+ contract at a fixed price, you will instead declare the price at which you would be willing to enter into a REDD+ contract. The lowest $50 \%$ of the bids will be given REDD+ contracts, and they will be paid an amount equal to the lowest bid that was not accepted. The households with higher bids will not have REDD+ contracts and may instead harvest wood from the forest.

\section{Contract Period 5: Community Contract}

You will be randomly grouped into one of six small communities. As a group, you must discuss and decide whether to enter your community's forest into a REDD+ contract, at a payment rate of $\$ 50$ per household. You must figure out amongst yourself how to decide (e.g., majority vote, consensus, etc.) and, if you enter into a contract, how to divide the REDD+ payments among yourselves. If a community enters into a REDD+ contract, no-one in the community can harvest wood from the forest.

\section{Contract Period 6: Community Contract + Fraud}

You will be in the same community as before and again decide collectively on whether to enter into a REDD+ contract and, if so, how to share REDD+ payments. But individual households in the group can now commit fraud: they can secretly harvest from the forest even though their community has entered into a REDD+ contract.

The community can collectively choose to police itself. If it does, each household pays $\$ 5$ and all member households will be monitored by trustworthy locals. This monitoring prevents illegal harvest because potential fraudsters are totally deterred from entering the forest.

If the community does not police itself, there is a chance it will be audited by the REDD+ Secretariat. The audit likelihood increases by $10 \%$ for each person in the community who commits fraud, because more harvest makes it easier to detect. Note that auditing happens at the community level: an entire community is either audited or not. If it is audited and fraud is found, no-one in the community will get REDD+ payments or harvest value (harvested wood must be returned), and each member of the community will be fined $\$ 70$.

So the order of actions for this contract period is:

1. Community decision: Join REDD+ or not?

2. If REDD+: Community decision: Engage in policing or not?

3. If no policing: Household decision: Conduct fraud or not?

4. Government action: each unpoliced REDD+ community audited with probability $10 \%$ times number of people committing fraud 


\section{"Money Growing on Trees" Recording Sheet}

Name:

My harvest value (playing card 1-10 or J (for joker or face card)):

My ID number (1 to \# participants) from spreadsheet:

My decisions and my earnings (fill in the table below as the contract periods progress):

\begin{tabular}{|c|c|c|c|c|c|c|c|c|c|c|}
\hline $\mathbf{C P}$ & Conditions & $\begin{array}{c}\text { CHOOSE: } \\
\text { Bid }\end{array}$ & $\begin{array}{l}\text { CHOOSE: } \\
\text { REDD+? }\end{array}$ & $\begin{array}{c}\text { CHOOSE: } \\
\text { Fraud? }\end{array}$ & Audited? & $\begin{array}{c}\text { A } \\
\text { Farming } \\
\text { Income }\end{array}$ & $\begin{array}{c}\text { B } \\
\text { REDD+ } \\
\text { Payment }\end{array}$ & $\begin{array}{c}\text { C } \\
\text { Forest } \\
\text { Harvesting }\end{array}$ & $\begin{array}{c}\text { D } \\
\text { Policing, } \\
\text { Fines, etc. }\end{array}$ & $\begin{array}{l}\text { Earnings }= \\
\text { A+B }+ \text { C-D }\end{array}$ \\
\hline 1 & Baseline & & $\mathrm{N}$ & & & $\$ 70$ & $\$$ & $\$$ & & $\$$ \\
\hline 2 & Fraud & & $\mathrm{Y}$ & $\mathrm{N}$ & $\mathrm{Y}$ & $\$ 70$ & $\$$ & $\$$ & $\$$ & $\$$ \\
\hline 3 & Uncertainty & & $\begin{array}{ll}\mathrm{Y} & \mathrm{N}\end{array}$ & & & $\$ 70$ & $\$$ & $\$$ & & $\$$ \\
\hline 4 & Auction & $\$$ & $\mathrm{Y} \quad \mathrm{N}$ & & & $\$ 70$ & $\$$ & $\$$ & & $\$$ \\
\hline 5 & Community & & $\mathrm{N}$ & & & $\$ 70$ & $\$$ & $\$$ & & $\$$ \\
\hline 6 & Comm + Fraud & & $\mathrm{Y}$ & & & $\$ 70$ & $\$$ & $\$$ & $\$$ & $\$$ \\
\hline & & & & & & & & TOTAL & $\$$ & $\$$ \\
\hline
\end{tabular}

(Reminder: if in some round you commit fraud, are audited, and are fined, cross out your B and C columns for that round - their values are zero if you are caught cheating on a contract!) 


\section{Appendix II: “Money Growing on Trees" Background: Global Deforestation, PES, \& REDD+}

Over $50 \%$ of global forests have been converted to human use since the advent of modern agricultural practices (Millennium Ecosystem Assessment, 2005). Tropical forest area is decreasing at over 10 million hectares per year, with much of the deforestation occurring in developing countries (Bluffstone et al., 2013; Millennium Ecosystem Assessment, 2005; Pan et al., 2011). Forest degradation accounts for 11-24\% of annual greenhouse gas emissions (IPCC, 2014; Saatchi et al., 2011; Van der Werf et al., 2009).

Restoring forests and preventing forest degradation can be a vital part of reducing greenhouse gas emissions. The 2015 Paris climate accord committed to limit "the increase in the global average temperature to well below $2^{\circ} \mathrm{C}$ above preindustrial levels" and for the first time counted (toward emission reduction targets) countries' efforts to offset their emissions by planting or protecting forests (Griscom et al., 2017; Popkin, 2019). Bastin et al. (2019) find "there is room for an extra 0.8 billion hectares of canopy cover, which would store 205 gigatonnes of carbon." Curbing deforestation and forest degradation is also believed to be a very cost-effective way to address climate change and also support adaptation (Angelsen, 2009; McKenney et al., 2004; McKinsey \& Company, 2009; Stavins and Richards, 2005; Stern, 2006).

The UN's Reducing Emissions from Deforestation and forest Degradation (REDD+) program serves this purpose. REDD+ is a payment for ecosystem services (PES) system created under the UN's Framework Convention on Climate Change (UNFCCC, 2011). PES programs are market-based (a.k.a., incentive-based) approaches to environmental regulation and are a key part of the policy toolkit for goals like watershed management, reducing deforestation, species preservation, and managing non-point source pollution (Engel, 2016; Engel et al., 2008; Wunder, 2005).

PES programs use a market to connect the receivers and the providers of an ecosystem service. REDD+ creates a market for

\begin{tabular}{|l|}
\hline \multicolumn{1}{|c|}{ Flavors of REDD } \\
REDD: \\
Focus only on carbon sequestration; \\
allows no forest use \\
REDD+ (or REDD plus): \\
Sustainable forest management \\
Conservation of forests \\
Enhancement of carbon sinks \\
REDD++: \\
Low-carbon but high biodiversity lands \\
\hline
\end{tabular}
carbon sequestration and reduction in greenhouse gas emissions by linking providers of carbon sequestration with countries that are required by the UNFCCC (or otherwise committing) to reduce emissions. Effectively, the program provides incentives to release less, and sequester more, carbon in selected countries and for countries that are required to reduce emissions to fund these efforts by purchasing credits (Baker et al., 2019; Bluffstone, 2013; Bluffstone et al., 2013; Rakatama et al., 2017). The ' + ' in REDD+ signifies other co-benefits that have been added to the original REDD program (which was focused solely on carbon) to address potentially negative, unintended effects on non-carbon ecosystem services and mitigate the program's effects on the people who currently have claims to forests (Bluffstone, 2013; Bluffstone et al., 2013; Sims and Alix-Garcia, 2017).

REDD+ is expected to create an opportunity to increase investment in forest management. This investment can bring many benefits, including achieving critical development goals, enhancing forest governance, bolstering global conservation efforts, reducing carbon emissions and deforestation, and contributing to poverty reduction, particularly in communities that manage forests (Bluffstone et al., 2013; Economist, 2010; Sims and Alix-Garcia, 2017; Springate-Baginski and Wollenberg, 2010; Toni, 2011). As of 2014, about 64 counties were engaged in conducting about 300 pilot REDD+ projects (Sills et al., 2014; UN-REDD, 2015).

Community forestry management has generally been considered a successful means to not only to halt deforestation and forest degradation but also to craft institutional mechanisms for equitable benefit sharing in communities. About $25 \%$ of developing country forests, or three times as much as is owned by the private sector, is community owned (Agrawal et al., 2008; Bluffstone, 2013; Bluffstone et al., 2013; Chhatre and Agrawal, 2009). Therefore, the successful adoption of REDD+ in developing countries depends on the effectiveness of REDD+ in community-controlled settings. Community-controlled forestry requires coordination between community members, but, as discussed by Ostrom (1990, 2010), Bluffstone et al. (2013), and Agrawal et al. (2008), such coordination can be challenging. 


\section{References}

Agrawal, A., Chhatre, A., Hardin, R., 2008. Changing governance of the world's forests. Science, 320(5882), 1460-1462. Angelsen, A., 2009, Realising REDD+: National strategy and policy options. Cifor.

Baker, K., Baylis, K., Bull, G.Q., Barichello, R., 2019. Are non-market values important to smallholders' afforestation decisions? A psychometric segmentation and its implications for afforestation programs. Forest Policy and Economics, 100, 1-13.

Bastin, J.-F., Finegold, Y., Garcia, C., Mollicone, D., Rezende, M., Routh, D., Zohner, C.M., Crowther, T.W., 2019. The global tree restoration potential. Science, 365(6448), 76-79.

Bluffstone, R., 2013. Economics of REDD+ and community forestry. Journal of Forest and Livelihood.

Bluffstone, R., Robinson, E., Guthiga, P., 2013. REDD+ and community-controlled forests in low-income countries: Any hope for a linkage? Ecological economics, 87, 43-52.

Chhatre, A., Agrawal, A., 2009. Trade-offs and synergies between carbon storage and livelihood benefits from forest commons. Proceedings of the national Academy of sciences, 106(42), 17667-17670.

Economist, 2010, Keeping it in the Community. The Economics.

Engel, S., 2016. The devil in the detail: a practical guide on designing payments for environmental services. International Review of Environmental and Resource Economics, 9(1-2), 131-177.

Engel, S., Pagiola, S., Wunder, S., 2008. Designing payments for environmental services in theory and practice: An overview of the issues. Ecological economics, 65(4), 663-674.

Griscom, B.W., Adams, J., Ellis, P.W., Houghton, R.A., Lomax, G., Miteva, D.A., Schlesinger, W.H., Shoch, D., Siikamäki, J.V., Smith, P., 2017. Natural climate solutions. Proceedings of the national Academy of sciences, 114(44), 11645-11650.

IPCC, 2014. IPCC, 2014: climate change 2014: synthesis report. Contribution of Working Groups I. II and III to the Fifth Assessment Report of the intergovernmental panel on Climate Change. IPCC, Geneva, Switzerland, 151.

McKenney, D.W., Yemshanov, D., Fox, G., Ramlal, E., 2004. Cost estimates for carbon sequestration from fast growing poplar plantations in Canada. Forest Policy and Economics, 6(3-4), 345-358.

McKinsey \& Company, 2009. Pathways to a low-carbon economy: Version 2 of the global greenhouse gas abatement cost curve.

Millennium Ecosystem Assessment, 2005, Millennium Ecosystem Assessment General Synthesis Report: Ecosystems and Human Well-being. Millennium Ecosystem Assessment.

Ostrom, E., 1990, Governing the commons: The evolution of institutions for collective action. Cambridge university press.

Ostrom, E., 2010. Beyond markets and states: polycentric governance of complex economic systems. American economic review, 100(3), 641-672.

Pan, Y., Birdsey, R.A., Fang, J., Houghton, R., Kauppi, P.E., Kurz, W.A., Phillips, O.L., Shvidenko, A., Lewis, S.L., Canadell, J.G., 2011. A large and persistent carbon sink in the world's forests. Science, 333(6045), 988-993.

Popkin, G., 2019, How much can forests fight climate change. Nature, pp. 280-282.

Rakatama, A., Pandit, R., Ma, C., Iftekhar, S., 2017. The costs and benefits of REDD+: A review of the literature. Forest Policy and Economics, 75, 103-111.

Saatchi, S.S., Harris, N.L., Brown, S., Lefsky, M., Mitchard, E.T.A., Salas, W., Zutta, B.R., Buermann, W., Lewis, S.L., Hagen, S., 2011. Benchmark map of forest carbon stocks in tropical regions across three continents. Proceedings of the national Academy of sciences, 108(24), 9899-9904.

Sills, E.O., Atmadja, S.S., de Sassi, C., Duchelle, A.E., Kweka, D.L., Resosudarmo, I.A.P., Sunderlin, W.D., 2014, REDD+ on the ground: A case book of subnational initiatives across the globe. Cifor.

Sims, K.R.E., Alix-Garcia, J.M., 2017. Parks versus PES: Evaluating direct and incentive-based land conservation in Mexico. Journal of Environmental Economics and Management, 86, 8-28.

Springate-Baginski, O., Wollenberg, E., 2010, REDD, forest governance and rural livelihoods: the emerging agenda. CIFOR.

Stavins, R.N., Richards, K.R., 2005. The cost of U. S. forest-based carbon sequestration. Pew Center on Global Climate Change. 52, 52.

Stern, 2006. Stern Review: The economics of climate change. London, England: HM Treasury.

Toni, F., 2011. Decentralization and REDD+ in Brazil. Forests, 2(1), 66-85.

UN-REDD, 2015. Regions and Countries Overview, http://www.unredd.net/index.php?option=com unregions\&view=overview\&ltemid=495\#.

UNFCCC, 2011. Fact Sheet: Reducing Emissions from Deforestation in Developing Countries.

Van der Werf, G.R., Morton, D.C., DeFries, R.S., Olivier, J.G.J., Kasibhatla, P.S., Jackson, R.B., Collatz, G.J., Randerson, J.T., 2009. CO 2 emissions from forest loss. Nature geoscience, 2(11), 737.

Wunder, S., 2005. Payments for environmental services: some nuts and bolts. 


\section{Appendix III: "Money Growing on Trees" Instructor How-To:}

Before class:

- Prep spreadsheet:

- delete data if necessary

○ add or delete contract periods by pasting copies of worksheets or deleting worksheets (if so, adjust "Tot Earn" column and "summaries" worksheet)

- you can leave extraneous contract periods in, but if so the Tot Earn column will be wrong.

- Ensure that Excel on the computer that you will use to project the spreadsheet during the session is set to automatically perform calculations. ${ }^{1}$

- If desired, prep PowerPoint with basic info about treatments; though if you use a ppt it will require you to switch the projector back and forth between the spreadsheet and the ppt; alternately, you can just write info on the board

Bring to class:

- If you plan to pay: money (ones, theoretically up to $\$ 10$ per payee)

- Playing cards 1-10 (i.e., face cards taken out), plus as many jokers as possible (5-20\% of cards should be jokers); alternatively, you can use face cards in place of jokers

- Printed instructions

- If desired, REDD+ handout

What to do in class:

- Bring up spreadsheet (and, if desired, PowerPoint)

- Hand out instructions and tell them to read

- Hand out playing cards randomly; they're allowed to look at them and show them to others once they have them, but can't look at cards to choose their desired one

- Tell players to record their card numbers on the sheet

- Background:

- Climate change is a problem

- We can fight it by reducing sources or increasing sinks

- Some places are regulated or are self-regulating (voluntarily reducing emissions), so need to reduce emissions

${ }^{1}$ On a PC:

- 2003: Tools $>$ Options $>$ Calculation $>$ Calculation $>$ Automatic.

- 2007: Office button $>$ Excel options $>$ Formulas $>$ Workbook Calculation $>$ Automatic.

- 2010 and 2013: File $>$ Options $>$ Formulas $>$ Workbook Calculation $>$ Automatic. On a Mac:

- 2008: Excel Preferences $>$ Calculation $>$ Automatically. 
- Can do it directly - cut our own emissions

- Or indirectly - pay someone else to reduce a source or increase a sink

- This is what an offset is

- Deforestation is a significant source of GHG emissions and afforestation and forest management has a large potential as a GHG sink

- UN's climate initiative has been working on REDD+ as a way to generate offsets

- Reduce deforestation as compared to some baseline; here, the baseline is an expectation that it will be cut down

- It's a PES system: since the preserved forest is providing ecosystem services that are a global public good, PES system monetizes those benefits, i.e. internalized the externality to incentivize optimal conservation

- Basic information:

- You're rural households

- You do subsistence farming and exploit the local forest to support your family

- Your forest exploitation can hurt the forest, which is bad because the forest provides global public goods, including carbon sequestration

- Let's see how a payment for environmental services scheme can change your choices about whether to harvest from the forest

- Your earnings in a contract period come from:

- Farming Income - subsistence (usually \$70)

- Harvest Value - if you harvest from the forest, you get a value of $\$ 10 *$ your playing card

- REDD+ Payment - if you are in a REDD+ contract, you get a payment (usually \$50)

- (Policing or Fines) - in treatments where there can be fraud (cheating), you may lose money to police your community or as fines for cheating

- CP1: baseline

○ Write on board: $\$ 70$ payment, no fraud

- Everyone write down REDD+ decision

- Go around room and call out ID, harvest value, and REDD+ decision, recording in decisions spreadsheet; tell them to record their ID number as we go around.

- Record quickly, and do it in an order that you can easily replicate each time (e.g., go across one row then the next, etc.)

- Record J for jokers and face cards

- Show earnings; show summary page

- Key things to discuss after round is complete:

- Marginal abatement cost is opportunity cost: foregone forest exploitation

- Cost effective conservation: minimize costs of reaching target

- Regulator may not know everyone's costs, so voluntary system with demand revelation is essential 
- Rationality and voluntary conservation

- Additionality: joker parcels were non-additional contracts

- CP2: baseline + fraud

$\circ$ Write on board: fraud possible. $25 \%$ chance of auditing. If caught, lose: REDD+ payment, harvest earnings, and $\$ 70$ fine

- Everyone write down both REDD+ decision and harvest decision

○ Go around room and call out both decisions

- Type anywhere in spreadsheet to determine who will be audited

- Then copy and paste audit column to make it permanent

- Call out ID numbers that committed fraud and are audited in case they can't see

- Show earnings; show summary page

- Key things to discuss:

- Verifiability

- Rational crime theories

- CP3: harvest uncertainty

- Write on board: $\$ 70$ payment, no fraud; harvest value has $50 \%$ chance of being 20x card and $50 \%$ chance of 0

- Everyone write down REDD+ decision

- Go around room and call out REDD+ decision, recording in decisions spreadsheet

- Type anywhere in spreadsheet to determine who gets shocked

- Then copy and paste shock column to make it permanent

- Call out ID numbers that got shock in case they can't see

- Show earnings; show summary page

- Key things to discuss:

- Decide based just on expected value? Did anyone change their decision versus the baseline round?

- CP4: auction

○ Write on board: auction! Write down dollar bid. Lowest $50 \%$ accepted and receive REDD+ payment of lowest not-accepted bid

- Draw a picture: a vertical ranking, marking the highest bid, the lowest bid, the median line

- All bids below the median line are accepted

- The bid just above the median is the lowest bid not accepted and this bid determine the REDD+ payment for everyone in the auction

- Everyone write down bid

○ Go around room and call out bids, recording in decisions spreadsheet

- Go to the summary page to show the median bid (everyone who bid BELOW this wins) and the resulting REDD+ payment

- Show earnings; show summary page

○ Key things to discuss: 
- If we know the distribution of opportunity costs, we can structure a flat payment and an auction to both conserve the same amount of land and both will be cost effective

- But if don't know the distribution of opportunity costs, the auction should reveal those values and thus get desired conservation target

- Auction theory: second price auction is incentive compatible (if your bid determines both whether you win and what you pay, you shade your bid down, so here it just determines whether you win)

- CP5: community

- Write on board: community

- 1. Decide as community whether to be in REDD+ contract \& how to divide up payments if so ( 5 minutes to talk)

- Note participation as a community is all or nothing

- Defining communities

- It's easiest to just group people in order of where they're sitting, but that means that people may be grouped with people they know, which reduces the fun a bit

- Can instead add a rand() row and sort in order of that and assign groups based on that, and then re-sort; or you could count people off into groups (count $1-2-3 \ldots$ etc. and then tell all the 1 's to get together, all the 2's, etc.)

O Once communities are defined, people need to get physically with their communities. You also need to record who's in which community; it's also easiest if you then sort the spreadsheet by "Comm \#" (column C) so that you can easily enter the group's decision all at once

$\circ$ Give them 5 minutes to make REDD+ contract and payment allocation decision

- Go around groups publicly and ask whether chose REDD+ contract and how divided up payments if so, recording decisions

- Show earnings; show summary page

○ Key things to discuss:

- This is more realistic; in many cases, individual contracts are not feasible

- Community governance literature, see Ostrom and many others, shows that sometimes it works well and sometimes not! Why, do you think?

- Equity and power within community

- CP6: community + fraud - this is the most complicated treatment, and takes the longest to run; you should definitely run CP5 before you run this so they get the hang of working with their groups

○ Write on board: community + fraud!

- 1. Decide as community whether to be in REDD+ contract \& how to divide up payments, including considering cases of fraud ( 3 minutes to talk) 
- 2. If in REDD+ decide as a community whether to police yourselves

- If police, fraud is deterred

- 3. If in a REDD + contract and do not police, then individuals decide whether to harvest (record privately on sheet and then fold sheet to hide)

- 4. Government audits each REDD+ contracts that don't police themselves with probability $10 \%$ times number of people who commit fraud - if find fraud, REDD + contract invalidated and whole community is fined

- Note participation in REDD+ is for everyone or no-one in a community, but the fraud decision is individual

- If your groups are going to be particularly large or small, you might want to change that $10 \%$ value to be smaller or larger respectively. You can do this in the "params" worksheet; it's the parameter "community perfraudster audit probability increment"

○ Use same communities as CP5, or if didn't do that treatment, just group the same way we suggest there

- If you have more than 10 communities, you'll need to go to the "params" worksheet and add higher "Comm \#" values to the block there

- Give them 5 minutes to make REDD+ contract and payment allocation decision, and, if REDD+, whether to police

- For any REDD+ / no policing communities:

- All group members walk away from their groups (1 minute or less) to write fraud decision and fold or hide paper when return to hide decision you can provide paper slips for this, or you can have them do it on their recording sheets

○ Go around groups publicly and ask whether chose REDD+ contract and how divided up payments if so and whether decided to police, recording decisions (including division of REDD+ payments if not uniform)

- If they did decide to police, open all decision papers and see if there was fraud; record it if so

- Randomly determine which REDD+ non-self-policed contracts are to be audited by typing somewhere in sheet to make the random numbers regenerate, then copy and paste-special (values only) the "Audit?" column to make it permanent

- For any that were audited, open all decision papers and see if there was fraud; record it if so

- Show earnings; show summary page

- Key things to discuss:

- Community enforcement; motives for and against enforcing in your neighborhood

- Pick people for payment

○ Go to summary page 
- Type anywhere in sheet to recalculate the random numbers that determine who will be paid; copy and paste-special (values only) to make permanent

- If you want more than two people, you can copy and paste the cells we have provided as many times as you like

○ Look at the "Dollars" column for those people to see their earnings

- Discuss! Our paper that accompanies this game provides discussion questions you can use for in-class and online discussions or written assignments. 